\title{
Arsenic in Eggs and Excreta of Laying Hens in Bangladesh: A Preliminary Study
}

\author{
Amalendu Ghosh', M.A. Awal', Shankar Majumder³, Mahbub Mostofa4, \\ Abul Khair ${ }^{5}$, M.Z. Islam ${ }^{6}$ D. Ramkishan Rao ${ }^{7}$ \\ 'Upazila Livestock Office, Netrokona Sadar, Netrokona, Bangladesh; ${ }^{2}$ Department of Pharmacology, ${ }^{3}$ Department of \\ Agricultural Statistics, ${ }^{4}$ Department of Pharmacology, Bangladesh Agricultural University, Mymensingh, Bangladesh; ${ }^{5}$ District \\ Livestock Office, Noakhali, Bangladesh; ' ${ }^{6}$ epartment of Pharmacology, Bangladesh Agricultural University, Mymensingh, \\ Bangladesh; ${ }^{7}$ National Institute of Food and Agriculture-USDA, USA
}

\begin{abstract}
The aim of this study was to detect arsenic concentrations in feed, well-water for drinking, eggs, and excreta of laying hens in arsenic-prone areas of Bangladesh and to assess the effect of arsenic-containing feed and well-water on the accumulation of arsenic in eggs and excreta of the same subject. One egg from each laying hen ( $\mathrm{n}=248)$ and its excreta, feed, and well-water for drinking were collected. Total arsenic concentrations were determined by atomic absorption spectrophotometer, coupled with hydride generator. Effects of arsenic-containing feed and drinking-water on the accumulation of arsenic in eggs and excreta were analyzed by multivariate regression model, using Stata software. Mean arsenic concentrations in drinkingwater, feed (dry weight [DW]), egg (wet weight [WW]), and excreta (DW) of hens were 77.3, 176.6, 19.2, and 1,439.9 ppb respectively. Significant $(\mathrm{p}<0.01)$ positive correlations were found between the arsenic contents in eggs and drinking-water $(\mathrm{r}=0.602)$, drinking-water and excreta $(\mathrm{r}=0.716)$, feed and excreta $(\mathrm{r}=0.402)$ as well as between the arsenic content in eggs and the age of the layer $(\mathrm{r}=0.243)$. On an average, $55 \%$ and $82 \%$ of the total variation in arsenic contents of eggs and excreta respectively could be attributed to the variation in the geographic area, age, feed type, and arsenic contents of drinking-water and feed. For each week's increase in age of hens, arsenic content in eggs increased by $0.94 \%$. For every $1 \%$ elevation of arsenic in drinking-water, arsenic in eggs and excreta increased by $0.41 \%$ and $0.44 \%$ respectively whereas for a $1 \%$ rise of arsenic in feed, arsenic in eggs and excreta increased by $0.40 \%$ and $0.52 \%$ respectively. These results provide evidence that, although high arsenic level prevails in well-water for drinking in Bangladesh, the arsenic shows low biological transmission capability from body to eggs and, thus, the value was below the maximum tolerable limit for humans. However, arsenic in drinking-water and/or feed makes a significant contribution to the arsenic accumulations in eggs and excreta of laying hens.
\end{abstract}

Key words: Arsenic; Drinking-water; Egg; Excreta; Feed; Laying hen; Bangladesh

\section{INTRODUCTION}

Arsenic toxicity is a global health problem affecting millions of people. It is present ubiquitously in the environment and is released from both natural and man-made sources (1). Drinking-water is now recognized as the major source of human intake of arsenic in its most toxic (inorganic) forms. The

Correspondence and reprint requests:

Dr. Amalendu Ghosh

Upazila Livestock Officer

Netrokona Sadar

Netrokona

Bangladesh

E-mail: amalend_ghosh@yahoo.com arsenic disaster of Bangladesh has been called the most terrible environmental catastrophe of the twentieth century. The extent of this environmental disaster is greater than any other recorded in human history (2). It was estimated that groundwater in 59 out of 64 districts of Bangladesh is contaminated with arsenic (3).

Several studies indicated that irrigation with contaminated groundwater have significantly increased arsenic levels in agricultural soils $(4,5)$. Food crops grown on arsenic-contaminated soil can accumulate high levels of arsenic in seeds, stem, and leaves, which adds arsenic in food-chain of man and animals $(4,6)$. Bangladesh populations are getting arsenic mainly through drinking contami- 
nated tubewell-water and through consumption of contaminated foods. Chronic intake of arsenic is strongly associated with an increased risk of liver, kidney, skin and lung cancer $(7,8)$; cardiovascular disease $(9,10)$; and an increase in the mortality rate (11). Besides these, many other toxic effects of arsenic have been reported. Examples are its compromising effect on some immune functions (12-14), inhibition of neurite growth (15), and oxidative myocardial and liver injury $(16,17)$. WHO set the permissible limit of arsenic in drinking-water at 10 ppb (18). For Bangladesh, this is 50 ppb.

Poultry provides hard-cash income and creates employment opportunities for the rural and landless farmers in Bangladesh. Layer hens are now providing an unprecedented range of relatively low-cost egg and meat products for consumers. At present, most poultry farms in Bangladesh are being maintained with shallow well-water which contains relatively more arsenic than deep well-water (3). Hens raised with arsenic-rich drinking-water and feed may accumulate arsenic residue in their flesh, eggs, and excreta, which potentially leads to arsenic in the human food-chain (19). Public-health workers have expressed concern about the arsenic content of chicken meat for its role as human diet (20). Moreover, arsenic has been identified as a roadblock to potential solutions in animal waste management (21). The bioavailability of arsenic in foods, especially meat and eggs, and the arsenic risks to human health need to be assessed carefully. No data exist in Bangladesh on the level of arsenic in eggs and excreta of hens fed arsenic-rich feed and/or drinking-water. Thus, the objectives of the present study were to determine the arsenic concentration in well-water for drinking, feed, eggs, and excreta of laying hens in arsenic-prone areas of Bangladesh, and to assess the effect of arsenic in drinking-water and feed on the accumulation of arsenic in eggs and excreta of laying hens.

\section{MATERIALS AND METHODS}

\section{Study design}

A restricted observational (survey) study design was used in this work.

\section{Sampling site}

For this study, five worse arsenic-affected districts (Madaripur, Chandpur, Jessore, Satkhira, and Faridpur) of Bangladesh were selected, and field samples were collected from these districts. Information about these severely arsenic-contaminated areas was obtained from secondary sources (22) where concentrations of arsenic exceeding 1,000 ppb were reported in a few shallow tubewells.

\section{Sample-collection procedure}

A multistage sampling procedure was used for selecting the ultimate sample of the laying hens. In total, 62 layer farms were selected purposively from the aforesaid areas on the basis of pre-defined criteria of age (20-80 weeks) and availability of records on the source of feed and drinking-water; then, 248 commercial laying hens-four from each farmwere selected randomly. Samples were collected during March-May 2009 by interviewing the farmowners based on a pre-arranged questionnaire. The questionnaire was pre-tested and finalized after incorporation of feedback. Information about area, age, and history of feed and water consumption by the hens, including water source and depth of tubewells, were obtained on the basis of the questionnaire.

\section{Drinking-water for hens}

Tubewell-water samples consumed by hens were collected in $50 \mathrm{~mL}$ acid-washed polyethylene vial as previously described (23). Briefly, water samples were collected from mid-stream after pumping the tubewells vigorously for at least 10 minutes. Immediately after collection, samples were filtered with capsule filter $(0.45 \mu \mathrm{m}$ pore); then, the collecting vials were flushed with filtered water for about one minute. Vials were filled up to the top by filtered water. An aliquot of $100 \mu \mathrm{L}$ concentrated nitric acid was added (at the field prior to water collection) to acidify the sample to a $\mathrm{pH}<2$ and to prevent precipitation of iron and co-precipitation of arsenic (24).

Poultry feed

About $50 \mathrm{~g}$ feed (commercially-prepared or homemade with local ingredients), used as ration for chickens, was collected from each selected farm for arsenic analysis.

\section{Eggs and excreta}

With the consent of the proprietor, four laying hens from each of the selected farms were kept separately, one in each cage, with the bedding of chemically-clean and dry polyethylene mat. Generally, birds were confined in cages from 8-9 am until laying and dropping. Hens were allowed free access to sampled feed and water in cages. Eggs were collected, washed in tap-water and finally rinsed 
with distilled water. About 10-15 g excreta from each hen was collected in sterile zipper bags. Eggs and excreta were stored (eggs at $4{ }^{\circ} \mathrm{C}$ and excreta at $-20^{\circ} \mathrm{C}$ ) until analysis. When one or more layer hen(s) failed laying, egg(s) and/or excreta were collected on the subsequent day, following the procedure described, with equal numbers of birds from the respective farms.

\section{Sample preparation}

Poultry feed were oven-dried at $60{ }^{\circ} \mathrm{C}$ for $72 \mathrm{~h}$ and ground with a stainless steel grinder (Karl Kolb, Scientific Technical Supplies, West Germany). It was passed through 100-mesh sieve (poresize $0.149 \mathrm{~mm}$ ) and stored in desiccators. Before digestion, this was further oven-dried at $50{ }^{\circ} \mathrm{C}$ to get constant weight. About 0.3-0.5 g (DW) sample was taken into digestion tube. This was digested by block digester (M-24 plazas/samples, JP Selecta, Spain), using concentrated $\mathrm{HNO}_{3}$ and $30 \% \mathrm{H}_{2} \mathrm{O}_{2}$, heating at $120^{\circ} \mathrm{C}(25)$. For egg sample preparation, each egg was broken separately; yolk and albumin were homogenized by mixing in a blender. An aliquot of 3-4 mL (WW) egg homogenate was transferred to digestion tube. Samples were acid-digested in block digester, heating up to $150{ }^{\circ} \mathrm{C}$ by sequentially adding $5-7.5 \mathrm{~mL}$ triple acid mixture $\left(\mathrm{HNO}_{3}-10\right.$ parts, $\mathrm{HClO}_{4}-3$ parts, and $\mathrm{H}_{2} \mathrm{SO}_{4}-1$ part) and $3 \mathrm{~mL} \mathrm{H}_{2} \mathrm{O}_{2}$ in each digestion tube (26). Excreta samples were dried in oven at $50^{\circ} \mathrm{C}$ and ground for homogeneity by a blender. To remove coarse particles, blended samples were passed through one-mm sieve and stored in desiccators. Before analysis, it was further dried at $60^{\circ} \mathrm{C}$ in oven until reaching a constant weight. About 0.2-0.3 g (DW) ground excreta sample was taken in each digestion tube. Samples were digested using tri-acid mixture and $\mathrm{H}_{2} \mathrm{O}_{2}$ as egg homogenate (26). For complete digestion of carbonaceous material, heating was continued until colourless clear watery solution appeared. Finally, the digested samples were diluted to $50 \mathrm{~mL}$ by adding Millipore water and filtered through filter paper (Whatman No. 41). To validate the assay, every fifteenth sample-one blank and one standard reference material (SRM) -were digested as sample, following the same digestion procedures.

\section{Arsenic analysis}

Arsenic pentoxide $\left(\mathrm{As}_{2} \mathrm{O}_{5}\right.$ 1,000,000 ppb; Merck, Germany) was used as standard. It was reduced to trivalent state for constructing standard curve (27). One percent $\mathrm{HCl}$ was used as carrier liquid. Concentrations of arsenic in drinking-water and digested samples were determined using atomic absorption spectrophotometer, coupled with hydride generator (PG Instruments Ltd., UK), following prereduction with potassium iodide (KI) and potassium borohydride $\left(\mathrm{KBH}_{4}\right)$ to generate arsine $\left(\mathrm{AsH}_{3}\right)$ (28). Detection limit of the instrument for arsenic was two ppb. Quantification of arsenic was performed by spiking samples with working standard of $0,2.5,5,10,15$, and 20 ppb prepared immediately before use by serial dilution of the stock in $10 \% \mathrm{HCl}$. Samples exceeding the standard curve range were diluted with $1 \% \mathrm{HCl}$ to get standard curve range. The concentrations of arsenic in those samples were resolute multiplying by the dilution factor as appropriate. In every occasion, the linear correlation factor was bigger than 0.99. Determinations were performed in duplicate, having the relative error $<1 \%$. The salient features of instrument setting and carriers are summarized in Table 1.

\begin{tabular}{|ll|}
\hline $\begin{array}{c}\text { Table 1. Instrumental and chemical conditions employed for the determination of arsenic by flow injec- } \\
\text { tion-hydride generator-atomic absorption }\end{array}$ \\
\hline Parameter & Instrumental and chemical condition \\
\hline Light source & Ordinary hollow-cathode lamp \\
Measurement mode & Peak height \\
Carrier gas & Pure argon \\
Lamp current & $10 \mathrm{~mA}$ \\
Wavelength & $193.7 \mathrm{~nm}$ \\
Spectral bandwidth & $0.4 \mathrm{~nm}$ \\
Integration time & $15 \mathrm{sec}$ \\
Delay time & $5 \mathrm{sec}$ \\
Carrier gas-flow rate & $150 \mathrm{~mL} /$ minute \\
Carrier liquid & $1 \% \mathrm{HCl}$ \\
Blank solution & $10 \% \mathrm{HCl}$ \\
Reductant & $1.5 \% \mathrm{KBH}$ in $0.3 \% \mathrm{NaOH}$ \\
\hline
\end{tabular}




\section{Quality control}

Accuracy and precision of analyses were evaluated using commercially-available reference materials, with certified or recommended arsenic concentrations (Table 2). For eggs, known concentration of arsenic standard was analyzed to validate the assay. There was a good conformity between obtained arsenic concentrations in the reference materials and the reference values, signifying good analytical performance.
Nearly half of the hens (48.4\%) consumed water containing up to $50 \mathrm{ppb}$ of arsenic, followed by $27.4 \%$ of the hens consuming water tainted by arsenic between 51 and 100 ppb. The reminder of the hens consumed water tainted with arsenic at levels (ppb) of 101-150 (8.1\%), 151-200 (4.8\%), and $>200(11.3 \%)$. About 38.7\%, 27.4\%, and $33.9 \%$ of the hens consumed feed contaminated with arsenic levels of 100, 101-200, and >200 ppb respectively.

\begin{tabular}{|lcc|}
\hline \multicolumn{3}{|l|}{ Table 2. Reference materials analyzed for arsenic, together with collected samples in the present work } \\
\hline Reference material (Certified or recommended values) & Matrix & Recovery rate \\
\hline NIST 1643e $(60.45 \pm 0.72 \mathrm{ppb})$ & Water & 93 to $102 \%$ \\
NIST 1568a $(290 \pm 30 \mathrm{ppb})$ & Poultry feed/Excreta & 91 to $99 \%$ \\
Arsenic standard $(20 \mathrm{ppb})$ & Egg & 89 to $97 \%$ \\
\hline
\end{tabular}

\section{Statistical analyses}

Information on laying hens was stratified according to area, age, feeding status, drinking-water source, and arsenic levels in drinking-water and feed. Multiple comparisons of means were performed using $F$-test with a significance level at $\mathrm{p}<0.05$. Tukey's test was performed for multiple comparisons among the means in a particular item (29). Pearson's correlation coefficient was computed to evaluate the degree of linear relationship between two variables. Multivariate regression analysis, a logical extension of the multiple regression concept to allow for multiple responses, was done to explore the effects of the explanatory variables on dependent variables (30). Area (ref: Faridpur), age, feed type (ref: commercial feed), and arsenic contents in drinkingwater and feed were considered explanatory variables, and arsenic excreted through eggs and excreta were considered dependent variables. For the multivariate analysis, arsenic contents in drinking-water, feed, eggs, and excreta were log-transformed to remove the bad impact of the extreme values. All data were analyzed using the Statistical Package for Social Sciences (SPSS, Chicago, IL). Multivariate regression analyses were carried out using Stata (version 10) software (31).

\section{RESULTS}

Table 3 presents classification of laying hens based on the geographic area, age, sources of feed and drinking-water, and arsenic exposure levels from water and feed. Among the hens, $48.4 \%$ were fed home-made feed consisting of local ingredients while the remaining 51.6\% consumed commercial feed. About two-thirds of the hens consumed shallow tubewell-water, and the remaining consumed deep tubewell-water.
Arsenic content in well-water for drinking and feed supplied to the laying hens are documented in Table 4 . The overall mean arsenic concentration in drinking-water was 77.3 ppb (95\% CI: 66.6-88.0). Arsenic content in well-water up to 90 metre and above 90 metre depth differed significantly $(\mathrm{p}<0.01)$ whereas no significant difference $(\mathrm{p}>0.05)$ was observed between 45 metre and $>45-90$ metre depth. Significant difference $(\mathrm{p}<0.01)$ in arsenic concentration between commercially-prepared feed and the home-made feed prepared by local ingredients was also observed.

Area-wise arsenic concentrations in well-water for drinking, feed, eggs, and excreta of laying hens are summarized in Table 5. The overall mean arsenic concentration in feed (DW), eggs (WW), and excreta (DW) of layers were 176.6 ppb (95\% CI: 160.9 192.3), 19.2 ppb (95\% CI: 16.9-21.5) and 1,439.9 ppb (95\% CI: 1,321.2-1,558.7) respectively. Arsenic concentrations in drinking-water, feed, and excreta of laying hens varied insignificantly ( $p>0.05)$ at different locations. On the other hand, arsenic content in eggs differed significantly $(\mathrm{p}<0.01)$ from area to area.

Correlation between arsenic concentrations in eggs as well as excreta and drinking-water are presented in Fig. 1. The results show a strong significant $(\mathrm{p}<0.01)$ positive correlation between arsenic content in eggs and that in drinking-water $(r=0.602)$ as well as excreta and drinking-water $(\mathrm{r}=0.716)$. Likewise, quantity of arsenic in excreta was significantly $(\mathrm{r}=0.402, \mathrm{p}<0.01)$ correlated with the arsenic concentration in feed for the layers (Fig. 2). Results signify that more the arsenic in drinking-water, the more was the elevation of arsenic in eggs and 


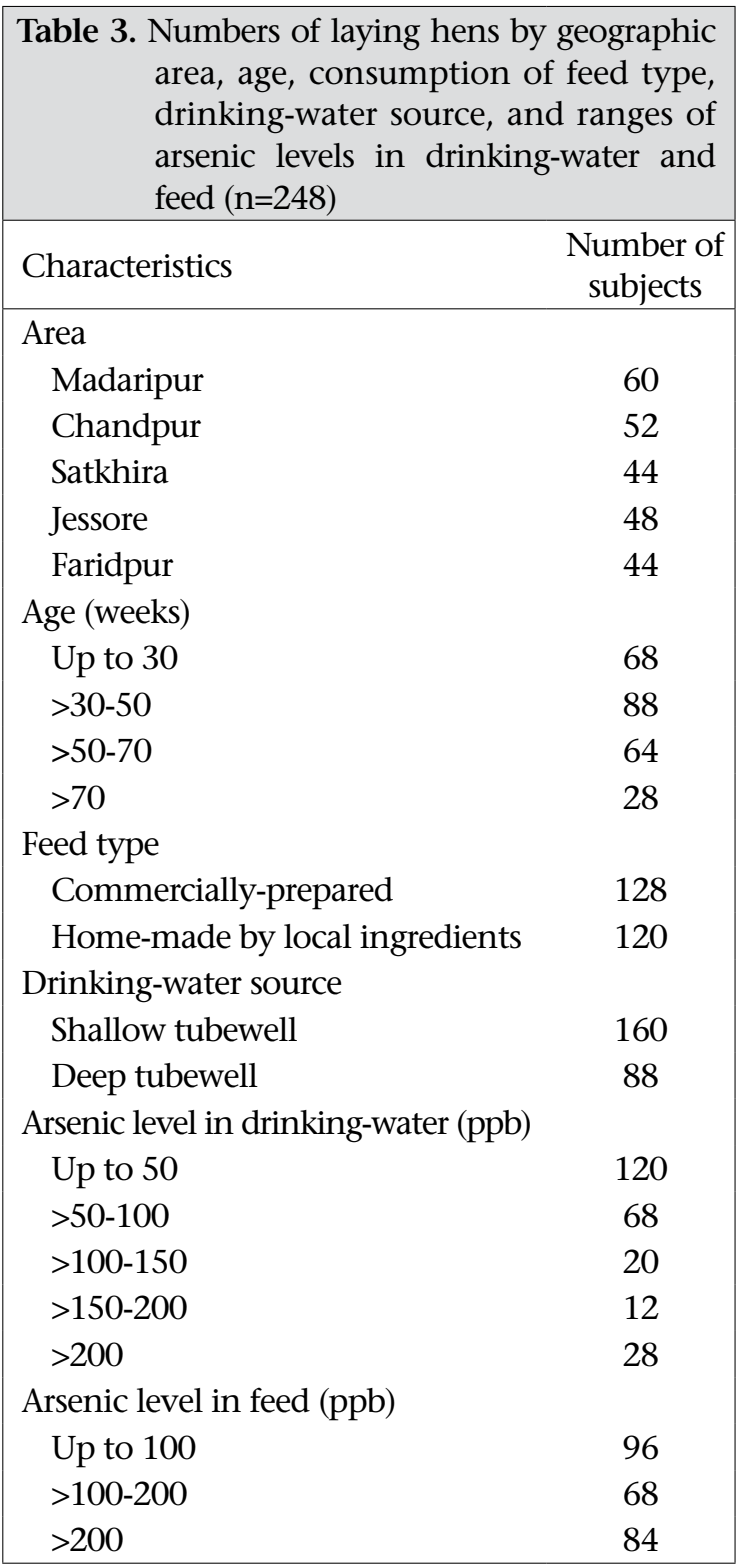

excreta. Furthermore, arsenic contents in eggs was significantly $(\mathrm{p}<0.01)$ correlated $(\mathrm{r}=0.243)$ with the age of layers but an insignificant $(p>0.05)$ correlation was observed in the arsenic content in excreta with the age of laying hens (Fig. 3).

The results of multivariate regression analysis are summarized in Table 6 . The significant $F$ values (and, therefore, $\mathrm{R}^{2}$ values) of the model reveal the perfectness of fitting the models to the data. The $\mathrm{R}^{2}$ values ( 0.55 and 0.82 ) imply that $55 \%$ and $82 \%$ of the total variation in arsenic content in eggs and excreta respectively could be due to the discrepancy in the area, age, feed type, and arsenic contents in drinking-water and feed. For this analysis, Faridpur was considered the reference area. Arsenic in eggs was significantly $(\mathrm{p}<0.01)$ higher at Madaripur compared to Faridpur. It could be expected that geometric mean of arsenic in eggs was [exp (0.45853)-1]x100 $=58.17 \%$ higher at Madaripur compared to Faridpur. Conversely, significantly lower $(\mathrm{p}<0.05)$ arsenic in eggs was observed at Chandpur compared to Faridpur, i.e. geometric mean of arsenic in eggs was $25.53 \%$ lower in Chandpur compared to Faridpur, which was $[\exp (-0.2947185)-1] \times 100=-25.53 \%$. Arsenic contents in eggs at other localities (Satkhira and Jessore) differed insignificantly $(\mathrm{p}>0.05)$ with that of Faridpur. However, area exerted no significant effect on the arsenic in excreta of laying hens. A significant $(\mathrm{p}<0.01)$ positive impact of age on the arsenic accumulation in eggs was observed. With the advancement of one week in age, arsenic content in eggs increased, on an average, by [exp (0.0093909)-1] x100=0.94\%, keeping other factors constant. However, arsenic content in excreta was not affected by age. A significant $(\mathrm{p}<0.01)$ mo-

\begin{tabular}{|c|c|c|c|}
\hline Variable & Arsenic concentration ${ }^{\dagger}$ & 95\% CI for mean & F value \\
\hline \multicolumn{4}{|l|}{ Tubewell-water } \\
\hline \multicolumn{4}{|l|}{ Depth-wise (metre) } \\
\hline Up to 45 & $114.0^{\mathrm{a}}$ & $99.8-128.3$ & \\
\hline$>45-90$ & $131.0^{\mathrm{a}}$ & $97.0-165.0$ & $75.4^{\star *}$ \\
\hline$>90$ & $6.6^{\mathrm{b}}$ & $6.1-7.1$ & \\
\hline \multicolumn{4}{|l|}{ Source-wise } \\
\hline Shallow tubewell ( $\leq 75$ metre) & $116.2^{\mathrm{a}}$ & $103.0-129.3$ & \\
\hline Deep tubewell (>75 metre) & $6.6^{\mathrm{b}}$ & $6.1-7.1$ & $149.6^{* \star}$ \\
\hline Overall & 77.3 & $66.6-88.0$ & \\
\hline \multicolumn{4}{|l|}{ Feed } \\
\hline Commercially-prepared & $88.4^{\mathrm{b}}$ & $81.1-95.7$ & \\
\hline Home-made by local ingredients & $270.7^{\mathrm{a}}$ & 249.8-291.7 & $278.8^{\star \star}$ \\
\hline Overall & 176.6 & $160.9-192.3$ & \\
\hline
\end{tabular}




\begin{tabular}{|c|c|c|c|c|}
\hline Item & Area & Arsenic concentration ${ }^{\dagger}$ & $95 \%$ CI for mean & F value \\
\hline \multirow[t]{6}{*}{ Drinking-water } & Madaripur & 90.5 & $64.9-116.1$ & \multirow{6}{*}{1.6} \\
\hline & Chandpur & 63.4 & $40.3-86.4$ & \\
\hline & Satkhira & 57.4 & $40.3-74.5$ & \\
\hline & Jessore & 84.7 & $63.1-106.2$ & \\
\hline & Faridpur & 87.6 & $57.1-118.0$ & \\
\hline & Overall & 77.3 & $66.6-88.0$ & \\
\hline \multirow[t]{6}{*}{ Feed } & Madaripur & 175.8 & $132.7-218.9$ & \multirow{6}{*}{1.1} \\
\hline & Chandpur & 161.9 & 133.8-190.1 & \\
\hline & Satkhira & 196.0 & $159.1-232.9$ & \\
\hline & Jessore & 156.5 & $127.4-185.6$ & \\
\hline & Faridpur & 197.6 & $163.5-231.8$ & \\
\hline & Overall & 176.6 & $160.9-192.3$ & \\
\hline \multirow[t]{6}{*}{ Eggs } & Madaripur & $28.0^{\mathrm{a}}$ & $22.1-34.0$ & \multirow{6}{*}{$7.6^{* *}$} \\
\hline & Chandpur & $12.2^{\mathrm{b}}$ & $8.5-15.8$ & \\
\hline & Satkhira & $12.8^{\mathrm{b}}$ & $9.5-16.1$ & \\
\hline & Jessore & $19.2^{\mathrm{ab}}$ & $13.7-24.6$ & \\
\hline & Faridpur & $21.8^{\mathrm{ab}}$ & $16.6-27.0$ & \\
\hline & Overall & 19.2 & $16.9-21.5$ & \\
\hline \multirow[t]{6}{*}{ Excreta } & Madaripur & $1,583.1$ & $1,289.7-1,876.5$ & \multirow{6}{*}{0.7} \\
\hline & Chandpur & $1,307.9$ & $1,024.8-1,590.9$ & \\
\hline & Satkhira & $1,377.7$ & $1,151.8-1,603.6$ & \\
\hline & Jessore & $1,422.9$ & $1,174.9-1,670.8$ & \\
\hline & Faridpur & $1,481.7$ & $1,213.1-1,750.4$ & \\
\hline & Overall & $1,439.9$ & $1,321.2-1,558.7$ & \\
\hline
\end{tabular}

notonous increase in arsenic contents in eggs and excreta was observed with increasing magnitude of arsenic in drinking-water and feed. On average, $0.41 \%$ and $0.44 \%$ arsenic were amplified in eggs and excreta respectively for $1 \%$ elevation of arsenic in drinking-water, keeping all other factors constant. Conversely, $1 \%$ increase in the arsenic level in feed resulted in $0.40 \%$ and $0.52 \%$ elevation of arsenic in eggs and excreta respectively, keeping all other arsenic exposure items constant.

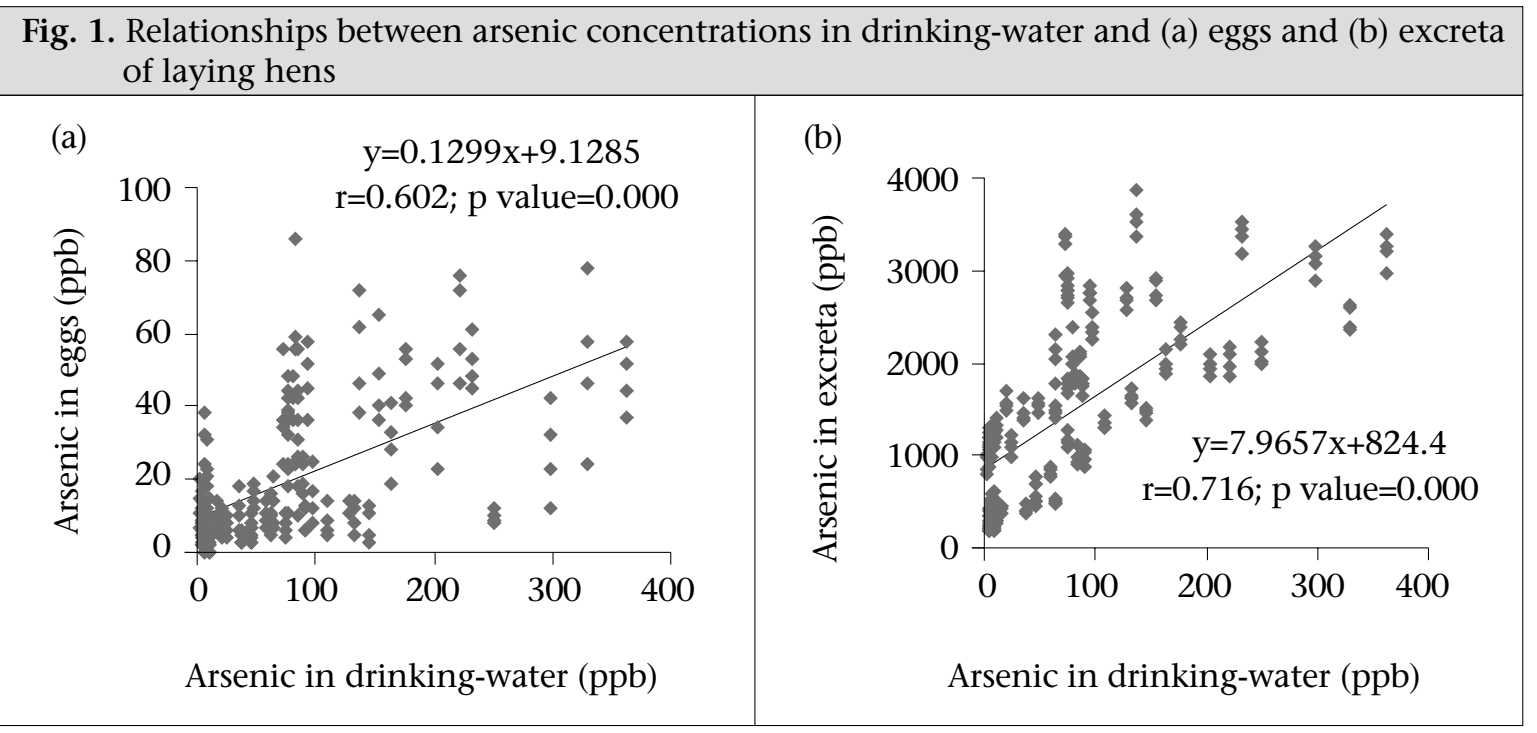


Fig. 2. Relationships between arsenic concentrations in feed and (a) eggs and (b) excreta of laying hens

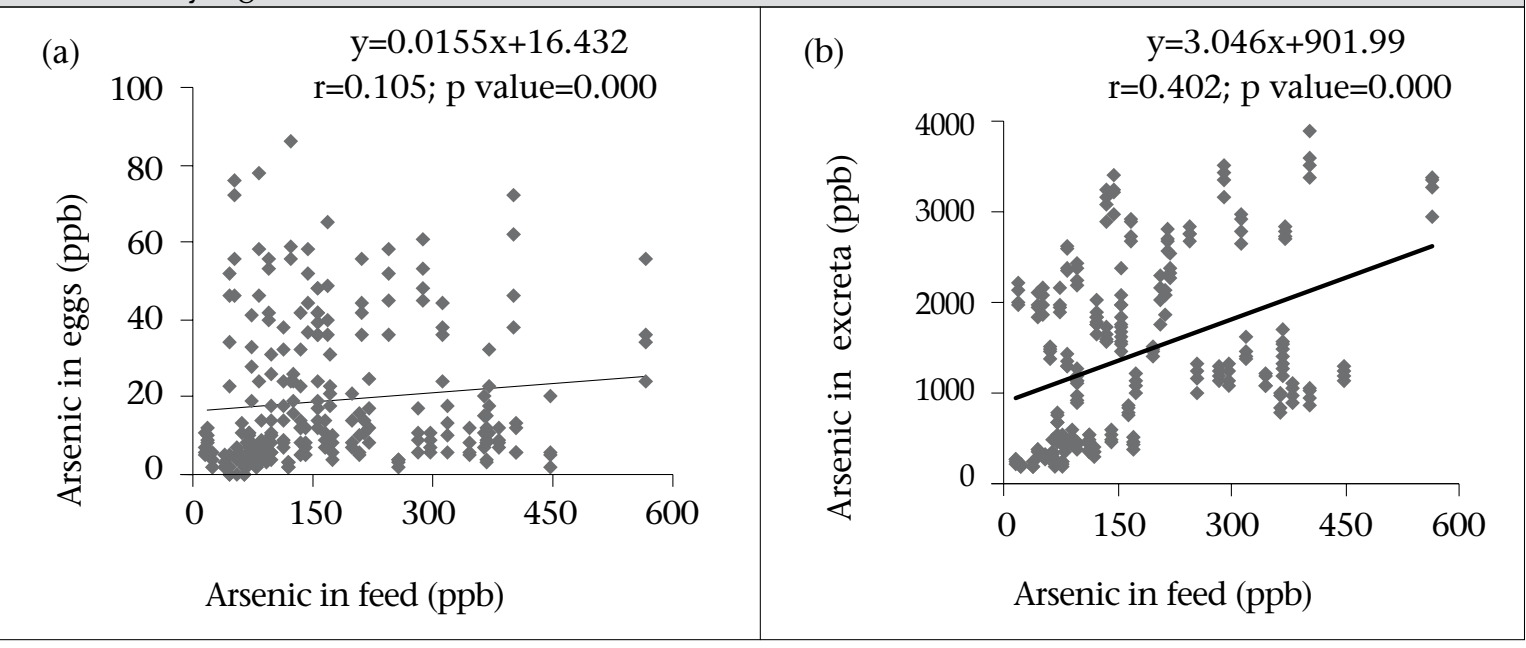

Fig. 3. Relationships between age and arsenic concentrations in (a) eggs and (b) excreta of laying hens

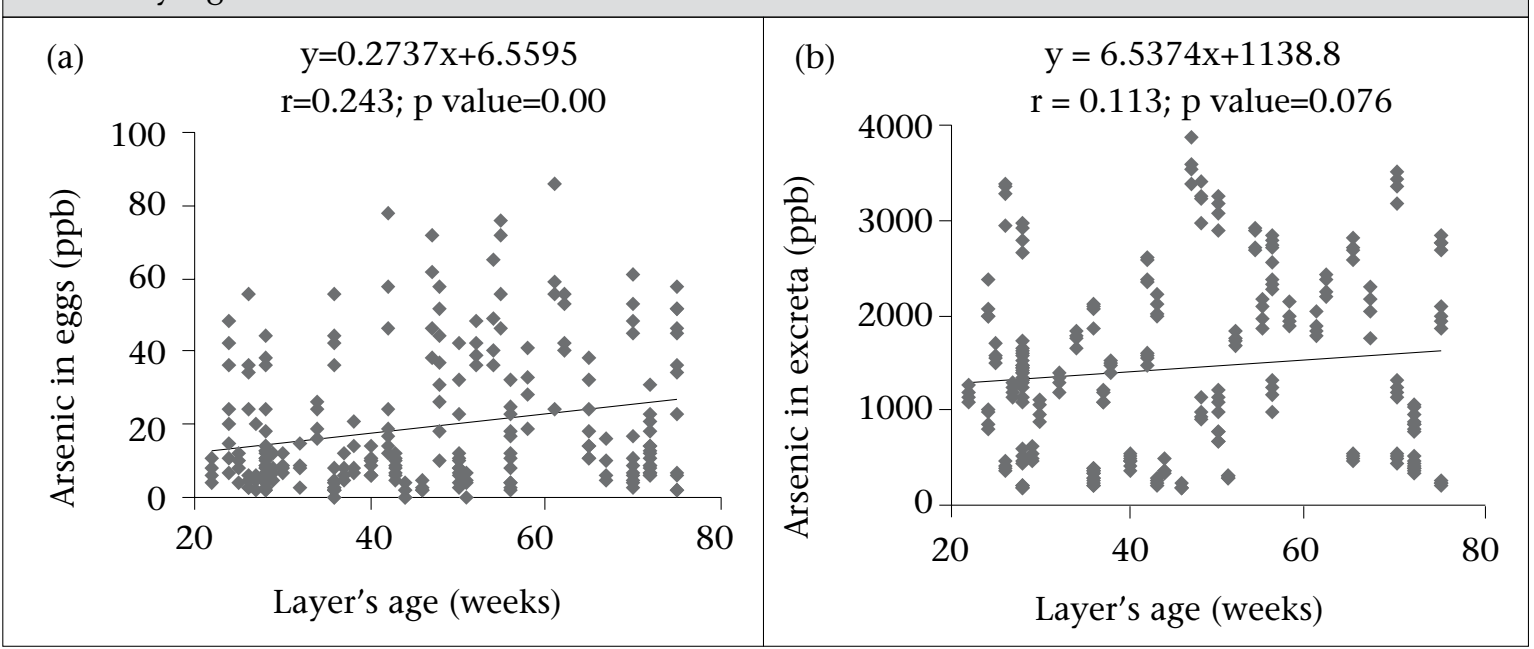

Table 6. Multivariate regression model for identifying the significant effects of arsenic exposure indices on arsenic concentrations in eggs and excreta of laying hens ${ }^{\dagger}$

Regression indices and explanatory variable

Intercept

\begin{tabular}{cc}
\multicolumn{2}{c}{ Dependent variable } \\
\hline Eggs & Excreta \\
$-1.33^{* *}(0.45)$ & $2.97^{* *}(0.23)$
\end{tabular}

Regression coefficients

Area (Reference: Faridpur)

Madaripur

Chandpur

Satkhira

Jessore

Age (weeks)

Feed type (Reference: Commercial feed)

Arsenic in drinking-water (ppb)

Arsenic in feed (ppb)

$\mathrm{R}^{2}$

F value

${ }^{*} \mathrm{p}<0.05 ;{ }^{* *} \mathrm{p}<0.01$; ${ }^{\dagger}$ Data on arsenic concentrations in drinking-water, feed, eggs and excreta were fitted to the model after log transformation; *Values in the parentheses stand for standard error 


\section{DISCUSSION}

The results of this study showed that wide ranges of arsenic are present in drinking-water, feed, eggs, and excreta of laying hens at different locations of Bangladesh. Arsenic contents in drinking-water detected in our study were higher than allowable limit of Bangladesh standard (50 ppb) but arsenic contents in eggs were within admissible limit of $500 \mathrm{ppb}$ for human consumption (32). The multivariate regression models fitted to the arsenic exposure data indicated that arsenic contents in eggs and excreta of laying hens were influenced by the arsenic-contaminated feed and drinking-water.

Drinking-water was analyzed for detection of possible sources of arsenic contamination in laying hens. We found wide ranges of arsenic contamination in drinking-water, which is consistent with the previous reports on different arsenicaffected areas of Bangladesh $(11,33)$. Arsenic concentrations in groundwater are increasing day by day throughout the world (34) and, with the progression of time, uncontaminated wells and unaffected areas are being affected, which poses a greater risk of arsenic toxicity. Increasing extraction of groundwater in Bangladesh might be a concern. Earlier reports suggest that concentration of arsenic decreases with the increment of tubewell depth $(3,35)$. However, we got a little bit higher arsenic in tubewell-water in between $>45-90$ metre depth than up to 45 metre depth, although the difference was insignificant. Comparatively lower arsenic in drinking-water in our study than reported previously $(11,33)$ and a little bit higher arsenic in well-water from $>45-90$ metre depth than up to 45 metre depth may be due to differences among geographical areas and small number of samples.

Detected arsenic concentration in feed for layers $(176.6 \mathrm{ppb})$ was very little compared to the maximum acceptable concentration of 2,000 ppb in complete feedstuffs (36). Presently, poultry feed chiefly contains mixtures of plant-based products, like maize and soybean cake. These are mostly imported from foreign countries where arsenic in groundwater and soil may be comparatively lower than in Bangladesh. Moreover, arsenic uptake by maize from soil is very low (37), resulting in little arsenic content in most of the poultry feeds. In this study, some of the feeds used for layer hens were prepared using local ingredients of Bangladesh, like rice-bran, wheat, and fish meal as protein and energy sources. These ingre- dients may restrain relatively more arsenic than imported items that may substantiate the arsenic loads of feed for layers.

Relatively small amount of arsenic was detected in eggs (19.2 ppb), which were close to that reported for White Leghorn layers $(24.6 \pm 0.3$ to $26.4 \pm 1.2$ $\mathrm{ppb}$ ) at Taiwan (38). Presence of small amount of arsenic in eggs of the layer hens even maintained with arsenic-rich drinking-water and feed indicates its lower transmission from blood plasma to the eggs. Epidemiological and experiment data demonstrated that arsenic can readily cross the placental barrier and that significant foetal exposure may occur when mothers are exposed to arsenic $(39,40)$. In spite of that, existence of diminutive arsenic content in eggs than FDA admissible limit of 500 ppb (32) is encouraging where arsenic catastrophe is a great problem.

Arsenic detected in excreta of laying hens in our study $(1,439.9 \mathrm{ppb})$ was slightly higher than previous report on excreta $(879 \pm 45$ to $926 \pm 56 \mathrm{ppb})$ of 32-week old White Leghorn layers (38). However, in 1 to 7 -week old broilers, $210 \pm 20$ to $580 \pm 110$ ppb arsenic was reported in excreta (41). Presence of relatively higher amount of arsenic in excreta in this investigation than the amounts reported previously $(38,41)$ is possibly due to simultaneous exposure to arsenic through feed and/or drinkingwater. It has been reported that the inclusion of arsenic-rich feed and drinking-water resulted in high arsenic in excreta (42). Arsenic in drinkingwater is chiefly inorganic in nature (43), which is generally much more toxic than organic forms. Staple foods accumulate mostly inorganic arsenic (44) whereas sea-foods, like fish meal, contain mostly organic arsenic. Inorganic arsenic is wellabsorbed in chick intestine (45) but it is excreted effectively. Organic arsenic in the form of arsenobetaine does not undergo biotransformation to other forms in animal body, and it is readily excreted through urine. Both inorganic and organic forms of arsenic substantiate the arsenic load in excreta. The use of arsenic-rich excreta and/or litter as fertilizer in agricultural fields contaminates the land (46) by elevating soil arsenic load. Longterm accumulation of heavy metals in agricultural soil has the potential to reduce soil productivity by inhibiting soil microbial populations (47) that may pose a risk to the ecosystem (48). Moreover, soil microbes convert arsenic to the most toxic inorganic forms (49). From soil, arsenic seeps into the nearest water tables (50) and, consequently, pollutes the environment. 
A significant elevation of arsenic in eggs and excreta resulted from the relative increment of arsenic in drinking-water and/or feed. The strong positive correlation between the arsenic contents in drinking-water and excreta supports this finding. However, arsenic in drinking-water is more detrimental to the living being than arsenic in feed owing to its inorganic nature. With the advancement of age, a concomitant increment of arsenic in eggs was observed. This indicates the aggregated accumulation pattern of arsenic. Positive correlation between arsenic contents in eggs and age further justifies the findings.

\section{Limitations}

Possible limitations of these analyses are that arsenic ingested other than feed and drinking-water were not considered during the analyses of data. Amounts of drinking-water and feed consumed by the hens were ignored. Some of these could affect the arsenic concentrations in layer products. However, the contribution of these limitations to the findings seems to be negligible. The effect of long-term consumption of high levels of arsenic through feed and drinking-water were not considered, which warrants further study.

\section{Conclusions}

The results suggest that arsenic-contaminated drinking-water and feed play a vital role in the elevation of arsenic in eggs as well as excreta of laying hens. High arsenic residue in excreta deserves urgent attention due to environmental concerns and possible recontamination of food-chain in case the excreta are used as fertilizer in conventional or organic farming. Although relatively small amounts of arsenic were obtained from eggs, it must be taken into account due to its detrimental effects on consumers, especially because there are multiple sources of simultaneous arsenic exposures. Although the drinking-water standard for arsenic has been reduced, the standard for arsenic residue in eggs has remained unchanged for decades. Moreover, initiatives to reduce arsenic exposure through drinking-water in Bangladesh are in progress. However, mitigation of the resulting catastrophe deserves urgent attention. Further research considering the limitations of this study would help gain a better picture of arsenic exposure among the people of Bangladesh through eggs and excreta of laying hens.

\section{ACKNOWLEDGEMENTS}

The authors acknowledge the financial contributions from the United States Department of Agri- culture (USDA)-Foreign Agricultural Service (FAS), USA; Ministry of Science, Information and Communication Technology (MoSICT), Bangladesh.

\section{REFERENCES}

1. Erbanova L, Novak M, Fottova D, Dousova B. Export of arsenic from forested catchments under easing atmospheric pollution. Environ Sci Technol 2008;42:7187-92.

2. Smith AH, Lingas EO, Rahman M. Contamination of drinking-water by arsenic in Bangladesh: a public health emergency. Bull World Health Organ 2000;78:1093-103.

3. Chakraborti D, Rahman MM, Das B, Murrill M, Dey S, Mukherjee SC et al. Status of groundwater arsenic contamination in Bangladesh: a 14-year study report. Water Res 2010;44:5789-802.

4. Zhu Y-G, Williams PN, Meharg AA. Exposure to inorganic arsenic from rice: a global health issue? Environ Pollut 2008;154:169-71.

5. Zhao F-J, McGrath SP, Meharg AA. Arsenic as a food chain contaminant: mechanisms of plant uptake and metabolism and mitigation strategies. Annu Rev Plant Biol 2010;61:535-59.

6. Das HK, Mitra AK, Sengupta PK, Hossain A, Islam F, Rabbani GH. Arsenic concentrations in rice, vegetables, and fish in Bangladesh: a preliminary study. Environ Int 2004;30:383-7.

7. Kaiser J. Environmental health. Second look at arsenic finds higher risk. Science 2001;293:2189.

8. Smith AH, Ercumen A, Yuan Y, Steinmaus CM. Increased lung cancer risks are similar whether arsenic is ingested or inhaled. J Expo Sci Environ Epidemiol 2009;19:343-8.

9. Yuan Y, Marshall G, Ferreccio C, Steinmaus C, Selvin $\mathrm{S}$, Liaw J et al. Acute myocardial infarction mortality in comparison with lung and bladder cancer mortality in arsenic-exposed region II of Chile from 1950 to 2000. Am J Epidemiol 2007;166:1381-91.

10. States JC, Srivastava S, Chen Y, Barchowsky A. Arsenic and cardiovascular disease. Toxicol Sci 2009;107:31223.

11. Argos M, Kalra T, Rathouz PJ, Chen Y, Pierce B, Parvez $\mathrm{F}$ et al. Arsenic exposure from drinking water, and all-cause and chronic-disease mortalities in Bangladesh (HEALS): a prospective cohort study. Lancet 2010;376:252-8.

12. Conde P, Acosta-Saavedra LC, Goytia-Acevedo RC, Calderon-Aranda ES. Sodium arsenite-induced inhibition of cell proliferation is related to inhibition of IL-2 mRNA expression in mouse activated T cells. Arch Toxicol 2007;81:251-9. 
13. Kozul CD, Ely KH, Enelow RI, Hamilton JW. Lowdose arsenic compromises the immune response to influenza A infection in vivo. Environ Health Perspect 2009;117:1441-7.

14. Kozul CD, Hampton TH, Davey JC, Gosse JA, Nomikos AP, Eisenhauer PL et al. Chronic exposure to arsenic in the drinking water alters the expression of immune response genes in mouse lung. Environ Health Perspect 2009;117:1108-15.

15. Frankel S, Concannon J, Brusky K, Pietrowicz E, Giorgianni S, Thompson WD et al. Arsenic exposure disrupts neurite growth and complexity in vitro. Neurotoxicology 2009;30:529-37.

16. Gonsebatt ME, Del Razo LM, Cerbon MA, Zúñiga O, Sanchez-Peña LC, Ramírez P. Arsenite induced oxidative damage in mouse liver is associated with increased cytokeratin 18 expression. Arch Toxicol 2007;81:619-26.

17. Manna P, Sinha M, Sil PC. Arsenic-induced oxidative myocardial injury: protective role of arjunolic acid. Arch Toxicol 2008;82:137-49.

18. World Health Organization. Guidelines for drinkingwater quality. 2nd ed. V. 2. Health criteria and other supporting information. Geneva: World Health Organization, $1996.973 \mathrm{p}$.

19. Al Rmalli SW, Haris PI, Harrington CF, Ayub M. A survey of arsenic in foodstuffs on sale in the United Kingdom and imported from Bangladesh. Sci Total Environ 2005;337:23-30.

20. Lasky T, Sun W, Kadry A, Hoffman MK. Mean total arsenic concentrations in chicken 1989-2000 and estimated exposures for consumers of chicken. Environ Health Perspect 2004;112:18-21.

21. Nachman KE, Graham JP, Price LB, Silbergeld EK. Arsenic: a roadblock to potential animal waste management solutions. Environ Health Perspect 2005;113:1123-4.

22. Ahmed KM, Huq SMI, Naidu R. Extent and severity of arsenic poisoning in Bangladesh. In: Naidu R, Smith E, Owens G, Bhattacharya P, Nadebaum P, editors. Managing arsenic in the environment: from soil to human health. Melbourne: CSIRO Publishing, 2006:525-40.

23. Pandey PK, Yadav S, Nair S, Pandey M. Sampling and preservation artifacts in arsenic analysis: implications for public health issues in developing countries. Curr Sci 2004;86:1426-32.

24. Clesceri LS, Greenberg AE, Trussell RR, editors. Standard methods for the examination of water and wastewater. 17th ed. Washington, DC: American Public Health Association, 1989.
25. Wolf A, Watson M, Wolf N. Digestion and dissolution methods for $\mathrm{P}, \mathrm{K}, \mathrm{Ca}, \mathrm{Mg}$ and trace elements. In: Peters J, Combs SM, Hoskins B, Jarman J, Kovar JL, Watson ME et al., editors. Recommended methods of manure analysis. Madison, WI: Cooperative Extension Publishing, 2003:30-8.

26. Cox DH. Arsine evolution-electrothermal atomic absorption method for the determination of nanogram levels of total arsenic in urine and water. J Anal Toxicol 1980;4:207-11.

27. Wahed MA, Chowdhury D, Nermell B, Khan SI, Ilias $\mathrm{M}$, Rahman $\mathrm{M}$ et al. A modified routine analysis of arsenic content in drinking-water in Bangladesh by hydride generation-atomic absorption spectrophotometry. J Health Popul Nutr 2006;24:36-41.

28. Samanta G, Chowdhury TR, Mandal BK, Biswas BK, Chowdhury UK, Basu GK et al. Flow injection hydride generation atomic absorption spectrometry for determination of arsenic in water and biological samples from arsenic-affected districts of West Bengal, India, and Bangladesh. Microchem J 1999;62:174-91.

29. Steel RGD, Torrie JH. Principles and procedures of statistics: a biometrical approach. 2nd ed. New York, NY: McGraw-Hill Book Company, 1980:185-6.

30. Johnson RA, Wichern DW. Applied multivariate statistical analysis. 5th ed. New Jersey, NJ: Prentice Hall, 2001:383-95.

31. StataCorp. Stata statistical software: release 10.0. College Station, TX: StataCorp LP, 2007.

32. US FDA Regulation. Code of Federal Regulations. 21 CFR 556.60. The Office of the Federal Register National Archives and Records. Washington, DC: Food and Drug Administration, 1992. (http://www.accessdata.fda.gov/scripts/cdrh/cfdocs/cfcfr/CFRSearch. $\mathrm{cfm}$ ?fr=556.60, accessed on 5 November 12).

33. Wasserman GA, Liu X, Parvez F, Ahsan H, Factor-Litvak P, van Geen A et al. Water arsenic exposure and children's intellectual function in Araihazar, Bangladesh. Environ Health Perspect 2004;112:1329-33.

34. Concha G, Nermell B, Vahter M. Spatial and temporal variations in arsenic exposure via drinkingwater in northern Argentina. J Health Popul Nutr 2006;24:317-26.

35. Hossain MA, Islam MA, Gani MO, Karim MA. Arsenic contamination in drinking water of tubewells in Bangladesh: statistical analysis and associated factors. In: Bundschuh J, Bhattacharya P, Chandrasekharam D, editors. Natural arsenic in groundwater: occurrence, remediation and management. Proceedings of the pre-congress workshop "Natural Arsenic in Groundwater (BWO 06)". 32nd International Geological Congress, 18-19 August 2004, Florence, Italy. London: Taylor \& Francis, 2005:163-9. 
36. European Commission. Opinion of the scientific committee on animal nutrition on the use of zinc in feedstuffs. Brussels: Health and Consumer Protection Directorate-General, European Commission, 2003:118.

37. Duxbury JM, Panaullah G. Remediation of arsenic for agriculture sustainability, food security and health in Bangladesh. Rome: Food and Agriculture Organization, 2007. 28 p. (FAO water working paper).

38. Chiou PWS, Chen KL, Yu B. Effects of roxarsone on performance, toxicity, tissue accumulation and residue of egg and excreta in laying hens. J Sci Food Agric 1997;74:229-36.

39. Hall M, Gamble M, Slavkovich V, Liu X, Levy D, Cheng Z et al. Determinants of arsenic metabolism: blood arsenic metabolites, plasma folate, cobalamin, and homocysteine concentrations in maternal-newborn pairs. Environ Health Perspect 2007;115:1503-9.

40. Ahlborn GJ, Nelson GM, Grindstaff RD, Waalkes MP, Diwan BA, Allen JW et al. Impact of life stage and duration of exposure on arsenic-induced proliferative lesions and neoplasia in $\mathrm{C} 3 \mathrm{H}$ mice. Toxicology 2009;262:106-13.

41. Anderson BK, Chamblee TN. The effect of dietary 3-nitro-4-hydroxyphenylarsonic acid (roxarsone) on the total arsenic level in broiler excreta and broiler litter. J Appl Poult Res 2001;10:323-8.

42. Morrison JL. Distribution of arsenic from poultry litter in broiler chickens, soil, and crops. J Agric Food Chem 1969;17:1288-90.
43. European Food Safety Authority. Opinion of the scientific panel on contaminants in the food chain on a request from the commission related to arsenic as undesirable substance in animal feed. (Question $\mathrm{N}^{\circ}$ EFSA-Q-2003-031). EFSA J 2005;180:1-35.

44. Williams PN, Price AH, Raab A, Hossain SA, Feldmann J, Meharg AA. Variation in arsenic speciation and concentration in paddy rice related to dietary exposure. Environ Sci Technol 2005;39:5531-40.

45. Fullmer CS, Wasserman RH. Intestinal absorption of arsenate in the chick. Environ Res 1985;36:206-17.

46. Arai Y, Lanzirotti A, Sutton S, Davis JA, Sparks DL. Arsenic speciation and reactivity in poultry litter. Environ Sci Technol 2003;37:4083-90.

47. Birch LD, Geiger G, Brandl H, Furrer G, Schulin R. The influence of heavy metals on the microbial decomposition of organic substances. Bodenkundl Ges Schweiz Dokument 1995;6:13-7.

48. Alloway BJ. Soil processes and the behaviour of heavy metals. In: Alloway BJ, editor. Heavy metals in soils. 2nd ed. London: Blackie Academic and Professional, 1995:11-37.

49. Stolz JF, Perera E, Kilonzo B, Kail B, Crable B, Fisher E et al. Biotransformation of 3-nitro-4-hydroxybenzene arsonic acid (roxarsone) and release of inorganic arsenic by Clostridium species. Environ Sci Technol 2007;41:818-23.

50. Garbarino JR, Bednar AJ, Rutherford DW, Beyer RS, Wershaw RL. Environmental fate of roxarsone in poultry litter. I. Degradation of roxarsone during composting. Environ Sci Technol 2003;37:1509-14. 